\title{
STUDI FAKTOR-FAKTOR TERJADINYA TINDAK KEKERASAN SEKSUAL PADA ANAK-ANAK
}

\author{
Kayus Kayowuan Lewoleba, Muhammad Helmi Fahrozi \\ Fakultas Hukum Universitas Pembangunan Nasional Veteran Jakarta \\ E-mail: agnespulo@gmail.com \\ Fakultas Hukum Universitas Pembangunan Nasional Veteran Jakarta \\ E-mail: helmifakhrazi@gmail.com
}

\begin{abstract}
The aims of this research is to study the understanding of sexual violence against children and also the factors that cause sexual violence in children. This research is an empirical legal research, therefore in this study the data used are primary data that is data obtained directly from the first source through interviews conducted for each informant and informant. In addition to primary data, this study also uses secondary data, namely through the study of documentary materials related to research problems. Then the analysis of this study uses a qualitative method using descriptive. The results of the study address discussions about the child's relationship to parents, siblings or parents where the child is used as an object of satisfying sexual needs. The rise of cases of sexy violence that occur in children lately can be submitted as multi-factor. There are factors that can be identified as two internal and external factors.
\end{abstract}

Keywords: Children; Factors; Sexual Harassment

\begin{abstract}
Abstrak
Tujuan utama penelitian ini adalah untuk mengetahui pengertian kekerasan seksual terhadap anak-anak serta apakah faktor-faktor penyebab terjadinya kekerasan seksual pada anak-anak. Penelitian ini merupakan penelitian hukum empiris, maka dari itu dalam penelitian ini data yang digunakan adalah data primer yaitu data yang diperoleh langsung dari sumber pertama melalui wawancara mendalam kepada setiap narasumber dan informan. Selain data primer penelitianinijuga menggunakan data sekunder yaitu melalui studi dokumen dari bahan-bahan pustaka terkait dengan masalah penelitian. Kemudian analisis penelitian ini menggunakan metode kualitatif dengan pendekatan deskriptif. Hasil penelitian menujukan bahwa kekerasan seksual terhadap anak adalah hubungan atau interaksi antara seorang anak dan seorang yang lebih tua atau orang dewasa seperti orang asing, saudara kandung atau orang tua di mana anak dipergunakan sebagai obyek pemuas kebutuhan seksual pelaku. Maraknya kasus kekerasan seksual yang terjadi pada anak akhir-akhir ini dapat dikatakan sebagai multi faktor. Adapun faktor-faktor tersebut dapat teridentifikasi sebanyak dua faktor internal dan eksternal.
\end{abstract}

Kata Kunci: Anak-anak; Faktor-faktor; Kekerasan Seksual 


\section{Pendahuluan}

Kewajiban Sebagai Negara hukum negara menjamin hak anak atas kelangsungan hidup, tumbuh dan berkembang serta berhak atas perlindungan dari kekekerasan dan diskriminasi sebagaimana tercantum dalam Undang-Undang Dasar Negara Republik Indonesia Tahun 1945 (UUD NRI 1945). Pesatmya arus globalisasi dan dampak negatif dari perkembangan di bidang teknologi informasi dan komunikasi, memunculkan fenomena baru yaitu kekerasan seksual terhadap anak. Bahwa kekerasan seksual terhadap anak merupakan kejahatan serius (serious crimes) yang semakin meningkat secara signifikan, mengancam dan membahayakan jiwa anak dari waktu ke waktu, merusak kehidupan pribadi dan tumbuh kembang anak serta mengganggu rasa kenyamanan, ketentraman, keamanan dan, ketertiban masyarakat.

Anak merupakan karunia Allah Tuhan Yang Maha Esa yang diberikan bagi orang tuanya. Sudah menjadi pemahaman bersama, karunia tersebut patut dijaga, dilindungi dan dikembangkan bakat dan potensinya sesuai dengan keinginan anakanak tersebut. Keluarga dan Negara patut memberikan perhatian yang khusus bagi pertumbuhan dan perkembangan anak. ${ }^{1}$

Tindak kekerasan yang dialami anak-anak sesungguhnya bukan sekedar problem psikologis yang hanya terjadi dilingkungan keluarga yang broken home, orang tua yang frustasi dan keluarga-keluarga miskin tak kuat menanggung tekanan hidup. Bagi kita semua, tindakan kekerasan terhadap anak-anak adalah masalah sosial, yang membutuhkan perhatian kolektif dari seluruh lapisan masyarakat, sebab korban dari kejadian ini tidak hanya dialami satu dua-dua unit keluarga atau sekedar ekspresi dari perilaku menyimpang di lingkungan keluarga yang frustrasi saja, melainkan jumlah anak yang menjadi korban dan siapa pelakunya boleh dikata telah melintasi batasbatas geografis dan komunitas, dapat menimpa siapa saja dan di mana saja.

Banyak bukti memperlihatkan bahwa tindak kekerasan tidak hanya menimpa anak-anak usia belasan tahun, tapi bayi yang tidak berdosa dan tidak mampu berbuat apa-apapun terkadang dianggap dapat memicu emosi orang dewasa yang berakibat pada terjadinya tindak kekerasan pada anak-anak. Tindak kekerasan pada anak-anak terjadi setiap waktu dan tempatnya pun tidak hanya diruang-ruang publik seperti di jalanan atau ditempat-tempat sepi, melainkan kasus ini bias juga terjadi di rumah yang sesungguhnya merupakan tempat berlindung paling aman bagi anak-anak. Rumah yang semestinya anak dapat bebas bermain, belajar atau membaca ternyata justru merupakan tempat yang paling tersembunyi dan aman bagi pelaku untuk melakukan tindak kekerasan kepada anak-anak. Di siang bolong atau malam hari, ketika seorang anak mesti beristirahat di kamar ditemani orang tuanya, ternyata juga seringkali justru menjadi obyek kekerasan seksual orang tua kandungnya sendiri.

Bagi anak-anak, tindakan child abuse, entah itu penganiayaan ringan, eksploitasi, pemukulan, pelecehan seksual, pemerkosaan, atau pembunuhan, sesungguhnya adalah mimpi buruk. Tindakan tersebut datang begitu saja tanpa permisi, dan tiba-tiba anak akan menjadi seorang pesakitan yang sama sekali tidak berdaya dan tak kuasa

1 Penjelasan Umum Peraturan Pemerintah Pengganti Undang-Undang Republik Indonesia Nomor 1 tahun 2016 Tentang Perubahan Kedua Atas Undang-Undang Nomor 23 Tahun 2002 Tentang Perlindungan Anak. 
untuk mengelak dari siksaan dan nista yang menderanya. Bedanya adalah kalau mimpi buruk akan menguap dan terlupakan takala anak bangun dari tidurnya. Tetapi tindak kekerasan yang dialami anak-anak dalam kehidupan nyata biasanya tetap membekas sepanjang waktu dan bahakan akan menimbulkan luka traumatik yang benar-benar mendalam, anak menjadi inferior, frustrasi, ketakutan, dan biasanya memilih berdiam diri sembari menahan penderitaan yang selalu membayang dikepalanya. Sebagai sebuah fakta sosial, tindak kekerasan dan pelanggaran terhadap hak-hak anak pada awalnya kurang memperoleh perhatian publik secara serius, karena tindakan ini biasanya dianggap hanya bersifat kausistis dan terjadi pada keluarga yang bermasalah. ${ }^{2}$ Tindak kekerasan terhadap anak-anak baru memperoleh perhatian publik lebih serius takala korban-korban tindak kekerasan yang dilakukan orang dewasa kepada anak-anak jumlahnya makin meluas, korban bertambah makin banyak dan menimbulkan dampak yang sangat menyengsarakan bagi anak-anak.

Anak adalah bagian yang tidak terpisahkan dari keberlangsungan hidup manusia dan keberlangsungan suatu bangsa dan negara. Dalam konstitusi Indonesia anak memiliki peran strategis yang secara tegas dinyatakan bahwa negara menjamin hak setiap anak atas kelangsungan hidup, tumbuh dan berkembang serta atas perlindungan dari kekerasan dan diskriminasi. Oleh karena itu kepentingan terbaik bagi anak patut dihayati sebagai kepentingan tebaik bagi kelangsungan hidup umat manusia. Anak Perlu mendapat perlindungan dari dampak negatif perkembangan pembangunan yang cepat, arus globalisasi di bidang komunikasi dan informasi, kemajuan ilmu pengetahuan, serta perubahan gaya dan cara sebagaian hidup orang tua yang telah membawa perubahan sosial yang mendasar dalam kehidupan masyarakat yang sangat berpengaruh besar terhadap perilaku anak. ${ }^{3}$

Berdasarjan penjelasan di atas idealnya perlindungan terhadap anak dari segala macam bentuk tindak kekerasan seharusnya dapat tercapai secara optimal, namun hal ini masih jauh dari apa yang diharapakan. Sesungguhnya tidak sedikit anak-anak terpaksa dan harus terlibat dalam situasi yang tidak menyenangkan atau bahakan menjadi korban dari suatu perlakuan yang menyakitkan, baik oleh pelaku tindak kejahatan yang professional, seperti premanisme, pemerkosaan, perampokan dan lain sebagainya. Kasus kekerasan terhadap anak setiap tahun mengalami peningkatan secara signifikan. Tidak ada data yang pasti berapa jumlah kasus kekerasan yang terjadi pada anak-anak. Data-data yang dihimpun beberapa lembaga hanya mencerminkan fenomena puncak gunng es, artinya data yang disajikan tidak meggambarkan fakta yang sebenarnya. Minimnya data tentang kasus kekerasan terhadap anak ini terjadi karena kebiasaan masyarakat yang meletakan persoalan ini sebagai irusan interen keluarga, dan karenaya tidak layak atau tabu untuk diekspos keluar secara terbuka.

Peningkatan tersebut tidak hanya dari segi kuantitas atau jumlah kasus yang terjadi, bahakan juga dari kualitas. Llebih tragis pelakunya adalah kebanyakan dari lingkungan orang terdekata seperti orang tua kandung, tiri, paman, sopir tetangga, guru dan lain-lain. Dampak dari kekerasan seksual yang terjadi dapat mengakibatkan terjadinya kehamilan. Dampak yang timbul dari adanya kehamilan

${ }^{2}$ Bagong Suyanto, Sri Sanituti Hariadi dan Priyono Adi Nugroho, Tindak Kekerasan Terhadap Anak, Masalah dan Upaya Pemantauan, Kerja Sama Lembaga Perlindungan Anak (LPA) Jawa Timur dan UNICEF, Surabaya: Penerbit Lutfansa Mediatama. h. iii.

${ }^{3}$ Penjelasan Umum Atas Undang-Undang Republik Indonesia Nomor 11 Tahun 2012 tentang Sistem Peradilan Pidana Anak. 
tersebut menyebabkan resiko gangguan psikologis seperti stress, depresi, berhenenti sekolah dan penganiayaan pada bayi. ${ }^{4}$

Di era digital saat ini, anak-anak muda terpapar dengan konten pornografi dan cybercrime karena mudahnya mengakses melalui internet. Tidak jarang banyak kasus kekerasan seksual yang terjadi di Indonesia karena terpengaruh melalui internet. Di Indonesia sendiri jumlah anak - anak yang mengalami korban tindak pidana kekerasan seksual menurut catatan resmi International Labour Organization (ILO) dan diperkuat dengan oleh United Nation Childrens Fund (UNICEF) mencapai 70.000 orang setiap tahunya ${ }^{5}$ dan dari jumlah tersebut 21.000 ada di pulau Jawa. ${ }^{6}$ Menurut UNICEF data prefelensi nasional tentang kekerasan seksual di Indonesia jumlahnya terbatas. Sebagian besar data kejadianya hanya tersedia di media publik seperti dilaporkan oleh beberapa organisasi masyarakat sipil atau Non Government Organization (NGO). ${ }^{7}$

Berdasarkan Survei terbaru Demografi Kesehatan'diperkirakan 17 anak perempuan yang menikah di Indonesia menyumbang terhadap adanya kasus kekerasan seksual yang sangat beresiko dan sangat nyata yang dilakukan di rumah oleh pasanganya. ${ }^{9}$ Gadis remaja yang menikah pada usia antara 15-19 tahun, berpotensi kena dampak resiko dari perkawinan anak. Beberapa peneliti feminis Indonesia berpendapat bahwa kekerasan seksual dalam pernikahan, termasuk terhadap anak perempuan, adalah perilaku yang diterima secara luas dan korban tidak mungkin untuk mencari bantuan kepada tetangga atau pemimpin di desa/wilayahnya, mereka cenderung untuk tidak ikut campur tangan urusan rumah tangga orang lain. ${ }^{10}$

Dalam kurun waktu tujuh tahun terakhir, 2011-2017, Kopmisi Perlindungan Anak Indonesia (KPAI) telah menerima sebanyak 27.845 pengaduan kasus yang didapat dari pengaduan langsung, pengaduan online dan pengaduan melalui surat/telepon. Selama tahun 2017 KPAI menerima sebanyak 3.849 aduan, di mana aduan mengenai Anak Berhadapan dengan Hukum $(\mathrm{ABH})$ menjadi kasus yang paling banyak diadukan ke KPAI. Pengaduan kasus terhadap anak yang menjadi pelaku dan korban kekerasan seksual (pemerkosaan, pencabulan, sodomi/pedhofilia dsb) cukup dominan. Setiap tahunya, pengaduan anak yang menjadi pelaku dan korban kekerasan seksual selalu menempati pengaduan terbanyak yang diterima KPAI. Bahakan di tahun 2014, aduan kasus ini mencapai 1.217 kasus. ${ }^{11}$ Mudahnya akses terhadap konten

${ }^{4}$ Mukodin dan Sri Fariha H, Dampak Psikologis Pada Kehamilan Remaja, Midwiferia Vol 1, No. 2 Oktober 2015.

${ }^{5}$ Lihat UNICEF, Efectife Strategies to Combat Sexual Violence Against Women and Children: A Background Analysis.

${ }^{6}$ ECPAT International. (2012). Global Report on Situation of Comercial Sexual Exploitation of Children in Indonesia. Bangkok: ECPAT International. h. 2.

7 Supriyadi Widodo Eddyono, Ahmad Sofian, Anugerah Riski Akbari. (2016). Menguji Euforia Kebiri; Catatan Kritis atas Rencana Kebijakan Kebiri (Chemical Castration). Jakarta: Instititut for Criminal Justice Reform, ECPAT Indonesia, Mappi FH UI, Koalisi Perempuan Indonesia, Aliansi 99 Tolak Perpu Kebiri. h. 1.

${ }^{8}$ Ibid.

${ }^{9}$ Ibid.

${ }^{10}$ UNICEF, Op. Cit.

11 Catatan Akhir Tahun Komisi Nasional Perlindungan Anak Indonesia. (2017). Peningkatan Efektifitas Kinerja Pengawasan Penyelenggraan Perlindungan Anak. Jakarta: KPAI. h. 27. 
pornografi dan kurangnya pengawasan dalam pengasuhan baik dari orang tua maupun lingkungan, diindikasi menyebabkan banyaknya anak menjadi pelaku dan korban kekerasan seksual.

Salah satu isu mainstream yang aktual saat ini adalah anak korban kekerasan seksual yang terjadi didunia maya. Saat ini kita tidak bisa menghindarkan diri dari akses ke dunia internet dan media sosial yang begitu mudah, tidak terkecuali anakanak. Pada masa sekarang anak-anak bahakan sejak belum sekolahpun sudah dapat mengoperasikan gadget. Mereka sudah bisa mengakses berbagai program mulai game atau permainan yang kadang-kadanng tidak bebas dari muatan yang mengandung kekerasan, pornografi dan hal negatif lainnya. Sementara, bagi anak-anak yang sudah bersekolah bahakan ditingkat dasar, sudah menjadi bagian dari masyarakat yang aktif di berbagai media sosial seperti facebook, twitter, instagram, line dan lain sebagainya. Mudahnya mengakes konten pornogafi ini juga yang rentan membuat orang dewasa untuk melakukan kekerasan seksual terhadap anak-anak terutama jaringan predator anak kaum pedofilis. Di kalangan anak yang termasuk golongan digital native tentunya memilki akun media sosial. Karena hal ini seolah sudah menjadi kebutuhan dasar yang harus dipenuhi, namun dengan seiring dengan perkembangan tumbuh kembang anak, pola pikir anak, pergaulan anak dan lemahnya kontrol orang tua, tentu rentan menjadi korban atau pelaku yang mempertontonkan lekukan tubuhnya tanpa busana "sexting" di media sosial.

September 2017 Polda Metro Jaya mengungkap jaringan prostitusi anak dibawah umur di media sosial Facebook dan Whatsapp bernama "Loly Candy's Group 18+. Anggota grup di Facebook "Loly Candy's Group" sudah mencapai 7.497 orang, sedangkan di grup Whatsapp berjumlah 156 orang. Dalam grup tersebut, para anggota yang mayoritas tidak mengenal satu sama lain, wajib berkirim gambar atau video pelecehan seksual yang mereka lakukan terhadap anak-anak. Dalam beberapa bukti yang tersebar, beberapa anggota menceritakan pengalaman mereka mencabuli, hingga memberi trik memanipulasi korbannya, sembari tak lupa menyebarkan foto mereka. Pengelola admin sendiri, yang juga tersangka mendapatkan upah sebesar Rp.15.000,setiap ada anggota yang mengklik foto atau video. ${ }^{12}$

Di samping itu terungkap pula jaringan-jaringan pedofil dan LGBT melalui komunitas video gay kids dengan akun @VGKS yang berisi ribuan konten pornografi anak dan video anak yang sedang melakukan hubungan intim sesama jenis, adanya kecendrungan pelaku adalah anak yang pernah mengalami kekerasan seksual dan tidak dilakukan rehabilitasi, adapun penyebarnya menggunakan berbagai media sosial, memang dengan adanya platform tersebut dalam hal pembuatan, penyebaran dan transaksi sangat cepat. Dalam kasus ini memang bisa dilihat bahwa sudah adanya pergeseran budaya masyarakat, adanya perubahan perilaku seksual yang memang korbanya tidak hanya kepada anak perempuan, namun anak laki-laki juga menjadi korban. ${ }^{13}$

Bisnis prostitusi yang melibatkan anak-anak ini biasanya cukup rapi dikemas dalam berbagai modus yang didalamya juga terdapat unsur perdagangan anak. Anakanak dari keluarga miskin adalah sasaran empuk dari para predator kejahatan seksual anak hasil kajian beberapa lembaga menunjukan bahwa anak-anak korban kekerasan seksual mengalami trauma berat yang sulit disembuhkan karena mengalami luka

12 https://pinterpolitik.com/pedofilia_dalam_dunia_maya1/, (diakses Sabtu 3 Maret 2018)

${ }^{13}$ Catatan Akhir Tahun Komisi Nasional Perlindungan Anak Indonesia, Op. Cit., h. 94. 
baik secara fisik maupun psikis. Trauma atau luka batin akibat kekerasan seksual ini menurut beberapa riset juga dapat menjadi pemicu untuk anak korban kekerasan seksual dapat juga menjadi pelaku kekerasan seksual sebagai dampak lanjutan daripristiwa traumatis tersebut. Anak juga dapat mengalami disorentasi seksual jika mempunyai pengalaman sebagai korban kekeresan seksual sesama jenis atau homo seksual.

Kekerasan seksual yang terjadi pada anak-anak saat ini, adalah dampak dari perkembangn dunia modern, internalisasi modal pada jaman modern ini sudah tidak lagi semata-mata ditandai dengan meningkatnya pertukaran komoditi material. Pertukaran modal, ini justru yang terpenting, telah juga merambah ke dunia informasi dan hiburan. Hal yang terakhir ini sangat penting untuk disorot karena memiliki dimensi pelanggaran HAM karena melibatkan anak-anak.

Industri hiburan tumbuh untuk melayani kelas-kelas sosial yang memiliki waktu luang (leisure time). Para penikmat waktu senggang, bebas mempergunakan waktu dan uangnya untuk kepentingan apa saja. Kehadiran kelas sosial yang membutukan waktu luang inilah yang menumbuhkan industri hiburan, termasuk industri seks yang melibatkan anak-anak dengan berselubung dibalik industri pariwisata, komoditi seksual bernilai miliaran dollar setiap tahunya. Para petualang yang memiliki waktu sengggang dan uang selalu ingin mencoba hal-hal baru dan eksotis. Pertumbuhan industri ini telah membawa dampak yang sangat menghina harkat dan martabat manusia terutama anak-anak, di mana bertumbuhnya prostitusi anak-anak. Dengan berbagai macam cara, anak-anak muda belia baik laki-laki maupun perempuan dipaksa untuk bekerja dalam praktek prostitusi yang berkedok industri pariwisata. Ada beragam pekerjaan yang harus mereka lakukan seperti menjadi perempuan penghibur, penerima tamu, pelacur anak dan aneka pekerjaan lainnya. ${ }^{14}$

Komersialisasi terhadap anak-anak kedalam industri seks juga menjadi soal penting yang jarang tersentuh. David Brasil pernah mengatakan bahwa salah satu pusat prostitusi anak di Indonesia yang terkenal di mancanegara adalah Batam dan Bintan, di dua tempat ini sangat dikenal dengan istilah "kampung cinta" dan "peternakan ayam" yang setiap hari dikunjungi laki-laki Singapura yang membelanjakan dollarnya untuk kenikmatan seksual. Di dua wilayah ini sangat mudah dijumpai gadis penghibur yang di Singapura sendiri sulit di dapat. ${ }^{15}$

Berdasarkan latar belakang sebagaimana yang sudah dijabarkan di atas maka rumusan masalah dalam penelitian ini adalah, apakah pengertian kekerasan seksual terhadap anak-anak serta apakah faktor-faktor penyebab terjadinya kekerasan seksual pada anak-anak.

\section{Metode Penelitian}

Penelitian ini merupakan penelitian hukum empiris, maka dari itu dalam penelitian ini data yang digunakan adalah data primer yaitu data yang diperoleh

14 Yayasan Lembaga Bantuan Hukum Indonesia. (1997). 1996: Tahun Kekerasan, Potret Pelanggaran HAM. Jakarta: YLBHI. h. 246.

${ }^{15}$ David Brasil. (2005). Bisnis Seks di Singapura. Jakarta: Pustaka Primatama. h. 91. 
langsung dari sumber pertama melalui wawancara kepada narasumber. Selain data primer penelitian ini juga menggunakan data sekunder yaitu melalui studi dokumen dari bahan-bahan pustaka terkait dengan masalah penelitian. Analisis penelitian ini menggunakan metode kualitatif dengan pendekatan deskritif, yaitu suatu penelitian yang bermaksud untuk mendeskripskan dalam bentuk kata-kata dan bahasa pada suatu konteks khusus yang alamiah dengan menanfaatkan berbagai metode alamiah. ${ }^{16}$ Pembahasan permasalahan dalam penelitian ini menggunakan teori kekerasan, kekerasan seksual dan dan teori psikologi sosial.

\section{Hasil Dan Pembahasan}

\subsection{Pengertian Kekerasan Seksual Terhadap Anak-anak}

Maraknya tindak kekerasan erat hubungan dengan sifat agresif mahkluk hidup termasuk manusia untuk mempertahankan diri agar survive. ${ }^{17}$ Kekerasan secara sederhana diartikan sebagai ketidaknyamanan yang dialami seseorang akibat suatu tingkah laku agresif sebagai pelampiasan dorongan nurani untuk menyakiti dan mencederai yang dilakukan seseorang, kekerasan merupakan daya upaya untuk terjadinya suatu tindak pidana, definisi tentang kekerasan secara terminologis dan teori sangat beragam salah satunya adalah suatu tingkah laku agresif yang dilakukan seseorang terhadap orang lain secara sengaja untuk menyebabkan korban mengalami penderitaan lahir batin. Pada umumnya tindakan agresif dapat digambarkan sebagai pelampiasan dorongan naluri berhasil menyakiti atau mencederai pihak lain yang dijadikan sasaranya. Keberhasilan dari tindakan itu dengan sendirinya berakibat meredanya daya dorongan itu. Dari sinilah muncul satu teori kekerasan yaitu teori agresif-frustrasi (frustration-aggression theory) yang menerangkan adanya peraturan langsung antara derajat frustrasi tingkah laku yang dialami seseorang dengan timbulnya kecendrungan bertingkah laku agresif. ${ }^{18}$

Jika tingkat agresivitas dikaitkan langsung derajat frustrasi, maka tingkah laku yang dapat diklasifikasikan menjadi sangat luas karena bukan saja menimbulkan korban manusia saja melainkan juga harta benda. Sedangakan teori kekerasan lainnya yang dikenal dengan nama teori kekerasan pembelajaran sosial (social leraning theory), di mana menurut teori ini tindakan kekerasan pada umumnya adalah hasil proses pembelajaran dari interaksi individu dengan lingkungan sosialnya, termasuk lingkungan keluarga ${ }^{19}$. Dalam realitasnya kebersamaan keluarga adalah merupakan lingkungan pergaulan anak yan pertama dan utama.

Perilaku mengancam jauh lebih menonjol dari kekerasan terbuka, dan kekerasan defensif jauh lebih menonjol dari kekerasan agresif. Perilaku mengancam mengkomunikasikan pada orang lain suatu maksud untuk menggunakan kekerasan terbuka bila diperlukan. Orang yang melakukan ancaman sesungguhnya tidak bermaksud melakukan kekerasan, orang hanya mempercayai kebenaran ancaman dan kemampuan pengancam mewujudkan ancamanya. ${ }^{20}$ Dengan mengancam, ada sedikit

${ }^{16}$ Moelong Lexy. (2014). Metodologi Penelitian Kualitatif. Bandung: Remaja Rosdakarya.

${ }^{17}$ Muhamad Jafar Anwar. (2002). "Kekerasan dan Anti Kekekrasan". Majalah Amanah 31(16). h. 12

${ }^{18}$ Erich Fromm. (2000). The Anatomi of Human Destructivenes, diterjemahan oleh Imam Mutaqqin, "Akar Kekerasan Analisis Sosio-Psikologis atas Watak Manusia". Yogyakarta: Pustaka Pustaka Pelajar. h. xix-xxi.

${ }^{19} \mathrm{Ibid}$, h. 67-68.

${ }^{20}$ Ibid, h. 12. 
orang yang mengontrol orang lain. Ancaman dianggap sebagai bentuk kekerasan, merupakan unsur penting kekuatan (power), kemampuan untuk mewujudkan keinginan seseorang sekalipun menghadapi keinginan yang berlawanan. Ancaman menjadi lebih efektif jika sesorang mendemonstrasikan keinginan untuk mewujudkan ancamanya.

Menurut Romli Atasasmita berkaitan dengan masalah kejahatan, maka kekerasan sering merupakan pelengkap dari bentuk kejahatan itu sendiri. Bahakan, kekerasan telah membentuk suatu ciri sendiri dalam khasana tentang studi kejahatan. Semakin menggejala dan menyebar luas frekwensi kejahatan yang diikuti dengan kekerasan dalam masyarakat, maka semakin tebal keyakinan masyarakat akan penting dan seriusnya kejahatan semacam ini. Dengan demikian, pada giliranya model kejahatan ini telah membentuk persepsi yang khas di kalangan masyarakat. Tidaklah berbeda kiranya jika kita analogikan dengan perbuatan suap dari tingkat yang paling rendah sampai paling tinggi. ${ }^{21}$

Berdasarkan hal di atas, Romli Atasasmita menyimpulkan bahwa kekerasan merujuk pada tingkah laku yang pertama-tama harus bertentangan dengan undangundang, baik berupa ancaman saja maupun sudah merupakan suatu tindakan nyata dan memiliki akibat-akibat kerusakan terhadap harta benda dan fisik atau engakibatkan kematian seseorang. Istilah kekerasan digunakan untuk menggambarkan perilaku, baik yang terbuka (overt) atau tertutup (covert), dan baik yang bersifat menyerang (offensive) atau bertahan (deffensive), yang disertai dengan penggunaan kekuatan kepada orang lain. Oleh karena itu, ada empat jenis kekerasan yang diindentifikasi, pertama, kekerasan terbuka yaitu kekerasan yang dapat dilihat seperti perkelahian. Kedua, kekerasan tertutup yaitu kekerasan tersembunyi atau tidak dilakukan langsung, seperti perilaku mengancam. Ketiga, kekerasan agresif yaitu kekerasan yang dilakukan tidak untuk perlindungan tetapi untuk mendapatkan sesuatu, seperti penjabalan. Keempat, kekerasan defensive yaitu kekerasan yang dilakukan sebagai tindakan perlindunngan diri. Baik kekerasan agresif maupun defensif bisa bersifat terbuka atau tertutup. ${ }^{22}$

Kekerasan seksual terhadap anak menurut menuut End Child Prostitution In Asia Tourism (ECPAT) ${ }^{23}$ merupakan hubungan atau interaksi antara seorang anak dan seorang yang lebih tua atau orang dewasa seperti orang asing, saudara kandung atau orang tua di mana anak dipergunakan sebagai obyek pemuas kebutuhan seksual pelaku. Perbuatan ini dilakukan dengan menggunakan paksaan ancaman, suap, tipuan bahakan tekanan. Kegiatan-kegiatan kekerasan terhadap anak tersebut tidak harus melibatkan kontak badan antara pelaku dengan anak sebagai korban. Bentuk-bentuk kekerasan seksual itu sendiri bisa dalam tindakan perkosaan ataupun pencabulan. ${ }^{24}$

${ }^{21}$ Romli Atasasmita. (2005). Teori dan Kapita Selekta Kriminologi. Bandung: Refika Aditama. h. $63-64$.

${ }^{22}$ Jack D Douglas, Frances Chaput Waksler. Teori-Teori Kekerasan, Surabaya: Ghalia Indonesia dan Universitas Kristen Petra. h. 11.

${ }^{23}$ ECPAT Internasional adalah sebuah jaringan organisasi yang berada di lebih dari 75 negara bekerja untuk menghapuskan semua bentuk-bentuk eksploitasi seksual anak.

24 Sari, A P. "Penyebab Kekerasan Seksual terhadap Anak dan Hubungan dengan Pelaku" diakses dari http://kompas .com/indeks.php/red. 
Menurut deklarasi Wina umumnya ada 2 (dua) bentuk kejahatan seksual terhadap anak yakni segala bentuk eksploitasi dan kekerasan seksual terhadap anak yang dilakukan oleh orang dewasa. ${ }^{25}$ Kekerasan seksual secara jelas diungkapkan sebagai perbuatan yang mengandung aspek-aspek yang bernuansa kekerasan misalnya ancaman, pemaksaan, atau kekerasan fisik. ${ }^{26}$ Karakteristik utama dari kekerasam seksual ini adalah bahwa pelakunya adalah pihak yang memiliki posisi dominan, yakni orang dewasa dan kekerasan menjadi andalanya dalam melakkan aktivitas seksual.

Menurut Balck's Law Dictionary, yang dimaksud dengan Child Sexual Abuse atau kekerasan seksual adalah aktivitas seksual yang illegal yang dilakukan terhadap seseorang yang dibawah umur yang dilakukan oleh orang tua, penjaga/pengasuh, sanak saudara atau orang yang dikenalnya. ${ }^{27}$ Multifaktor diyakini oleh banyak ahli dalam memandang penyebab terjadinya kekerasan seksual terhadap anak. Posisi anak sebagai pihak yang lemah dan tak berdaya, moralitas masyarakat khususnya pelaku kekerasan seksual yang rendah, kontrol dan kesadaran orang tua dalam mengantisipasi tindak kekerasan seksual pada anak, kurangnya program edukasi dari pihak pemerintah yang bisa diakses oleh masyarakat dan masih banyak faktor yang lain. ${ }^{28}$

Pelecehan seksual, penyerangan seksual, kekerasan hingga perkosaan yang dialami oleh seorang anak sebagai korban (victim), secara psikologis merupakan pengalamam traumatik. Kekerasan seksual tersebut lebih merupakan trauma psikis dari pada fisik. Karena dapat menimbulkan gangguan jiwa yang disebut stress pasca trauma. Adapun gejala-gejala stress pasca trauma adalah terdapat stres yang berat dan jelas (kekerasan perkosaan) yang akan menimbulkan gejala penderitaan yang berat bagi hampir tiap korban. Penghayatan yang berulang-ulang dari trauma itu yang dibuktikan oleh terdapatnya paling sedikit satu dari hal berikut, ingatan berulang dan menonjol tentang peristiwa tersebut, mimpi-mimpi berulang dari peristiwa tersebut, timbulnya secara tiba-tiba perlaku atau perasaan seolah-olah peristiwa traumatik itu timbul kembali, karena berkaitan dengan suatu gagasan atau stimulus/rangsangan lingkungan. ${ }^{29}$ Kekerasan seksual atau pelecehan seksual secara individual memang sangat luas terjadi pada siapa saja termasuk anak-anak. Batasan kekerasan seksual atau pelecehan dipengaruhi oleh nilai-nilai budaya dan pandangan pribadi seseorang tentang seksualitas. Pelecehan seksual tidak melulu terkait dengan sentuhan fisik atau secara verbal melalui ucapan yang bernada cabul, siulan atau kedipan mata juga termasuk dalam kategori pelecehan seksual.

Menurut Ketua Bagian Andrologi dan Seksologi Fakultas Kedokteran Universitas Udayana, Denpasar Bali sebagaimana dimuat dalam Harian Kompas

${ }^{25}$ Hal ini merupakan bagian dari Deklarasi World Congress yang diadakan pada Agustus 1996. Lihat Muhammad Farid. (1997). Kejahatan Seksual Terhadap Anak: Implementasi Konvensi Hak Anak (di Indonesia) dan Agenda Aksi dari Stockholm. Jakarta 20 Maret 1997. h. 50.

26 Memperdaya korban dengan menggunakan minuman yang memabukan juga termasuk dalam aspek-aspek kekerasan ini. Kristi Purwandari. (2006). Penguatan Psikologis untuk Menganggulangi Kekerasan Dalam Rumah Tangga dan Kekerasan Seksual. Jakarta: Program Kajian Wanita Pascasarjana Universitas Indonesia. h. 70.

${ }^{27}$ Bryan A. Garner. (1999). Blacks Law Dictionary. West Group ST. Paul, Minn.

${ }^{28}$ Wisnu Sri Hertinjung. The Dinamyc of Causes of Child Sexual Abuse Based on Availability of Personal Space and Privaci. Surakarta: Fakultas Psikologi Universitas Muhamadiyah Surakarta.

${ }^{29}$ Dadang Hawari. (2013). Kekerasan Seksual pada Anak. Jakarta: UI Press. h. 95. 
Selasa 12 Juni 2018, mengatakan manusia tidak peduli laki-laki dan perempuan, sejatinya adalah makhluk seksual. Mereka sama-sama memiliki dorongan seksual, membutuhkan hubungan seksual dan menginginkan kepuasan seksual. Nilai -nilai sosial yang berlaku membuat eksperesi seksual laki-laki dan perempuan berbeda. Perbedaan ekspresi seksual laki-laki dan perempuan tidak dipengaruhi struktur otak manusia. Secara fisiologis, otak laki-laki dan perempuan memang sedikit berbeda. Namun tidak berkaitan dengan ekspresi seksualnya. Nilai-nilai sosial yang berlaku membuat ekspresi laki-laki dan perempuan berbeda tegas Wimpie Pangkahila.

Sementara itu menurut Taufik Pasiak, Ketua Bagian Anatomi-Histologi Fakultas Kedokteran Universitas Sam Ratulangi (UNSRAT) Manado dalam harian yang sama, mengatakan pada perempuan, otak kananya lebih dominan dibandingkan dengan laki-laki. Akibatnya perempuan lebih emosional dalam menyikapi segala sesuatu. Menurut Taufik eksperesi seksulitas lebih banyak dipengaruhi proses evolusi manusia dibandingkan dengan struktur otaknya. Evolusi membuat laki-laki memandang seks sebagai alat pemuas nafsu dan kesenangan. Sementara bagi perempuan seks adalah sarana menjalin keintiman, kelekatan dan proses reproduksi. Laki-laki melihat seks adalah permainann yang menyenangkan, seks adalah adalah rekreasi sementara bagi perempuan seks adalah hal yang suci dan sakral. ${ }^{30}$

Pandangan ini muncul karena sejak awal evolusi manusia laki-laki lebih banyak berperan disektor publik atau di luar rumah sehingga peluang untuk berhadapan dengan hal-hal yang menegangkan dan mengancam jauh lebih besar. Situasi ini membuat mereka mudah stress dan lelah sehingga butuh hiburan melalui hubungan seks. Sebaliknya perempuan lebih banyak berperan di disektor domestik atau privat dan kurang menghadapi ketegangan dan ancaman. Situasi ini membuat perempuan di masa lalu cenderung tidak memcari hiburan sehingga mereka lebih pasif terhadap seksualitas. Namun meningkatnya kesetaraan jender, menguatnya partisipasi perempuan diruang publik, munculnya kesadaran laki-laki untuk membangun relasi baru dengan perempuan hingga perkembangan iptek membuat ekspresi perempuan terhadap seksualitas mulai berubah meskipun masih tetap terikat dengan nilai-nilai sosial budaya.

Kekerasan seksual terhadap anak-anak adalah masalah kejahatan kesusilaan atau moral offenses dan pelecehan seksual atau sexual harassment merupakan dua bentuk pelanggran atas kesusilaan yang bukan saja merupakan dua bentuk masalah (hukum) nasional suatu negara melainkan sudah merupakan masalah (hukum) semua negara di dunia atau merupakan masalah global. Masalah kejahatan kesusilaan dan pelecehan seksual terhadap anak-anak bukan dominasi mereka yang berasal dari goloungan ekonomi menengah atau rendah dan apalagi kurang atau tidak berpendidikan sama sekali, melainkan pelakunya sudah menembus semua strata sosial dari strata terendah sampai tertinggi. ${ }^{31}$

\subsection{Faktor-Faktor Penyebab Terjadinya Kekerasan Seksual Terhadap Anak-Anak}

30 "Seksulitas, Birahi Mnausia, antara Permainan dan Kesucian". Harian Kompas, Selasa 12 Juni 2018. h. 14.

${ }^{31}$ Lihat Romli Atasasmita. (1995). Kapita Selekata Hukum Pidana dan Kriminologi. Bandung: Mandar Maju. h. 103. 
Pembahasan faktor-faktor dari terjadinya kekerasan seksual terhadap anak berpedoman dari pengertian kriminologi berdasarkan pendekatan sebab akibat dan fakta kriminal, berusaha mencari jawaban kenapa kejahatan terjadi. Sedangkan kejahatan itu sendiri diartikan sebagai perilaku yang anti sosial yang telah dilarang dan dirumuskan dalam hukum positif sebagai kejahatan. Untuk mencari tahu latar belakang timbulnya kekerasan seksual terutama terhadap anak-anak, dapat merujuk pada pemikiran dari Sigmund Freud seorang ahli psikologi kenamaan terutama dalam bidang psikoanalisa. Berdasarkan teori dari Sigmund Freud bahwa ada dua hipotesis, yaitu manusia memiliki dorongan untuk melindungi diri (the drive of self preservation) dan dorongan untuk berkembang biak (the drive toward procreation). Dorongan untuk melindungi diri terus-menerus tidak mengalami hambatan dan tantangan, sehingga terabaikan atau tidak terlalu dipermasalahkan.

Sedangkan dorongan untuk berkembang biak perlu dibicarakan karena sering dihambat atau dibatasi oleh sosial budaya dan peradaban manusia. Pusat perhatian dari naluri kedua ini disebut libido dalam arti sempit yaitu seks. Libido atau seks yang terpusat pada tiga daerah erotis (erotic zones) pada tubuh manusia yaitu mulut (oral), lubang dubur (anal) dan alat kelamin (genital). Selanjutnya menurut Freud, kehidupan jiwa memiliki tiga tingkatan kesadaran, yakni sadar (conscious), prasadar (preconscious), dan tak-sadar (unconscious). Konsep dari teori Freud yang paling terkenal adalah tentang adanya alam bawah sadar yang mengendalikan sebagian besar perilaku. Selain itu, dia juga memberikan pernyataan bahwa perilaku manusia didasari pada hasrat seksualitas (eros) yang pada awalnya dirasakan oleh manusia semenjak kecil dari ibunya. ${ }^{32}$

Tuntutan untuk melampiaskan libido yang bersarang pada tubuh manusia itu tidak selalu dapat direalisasikan oleh manusia, penyebabnya adalah karena adanya norma-norma sosial, seperti norma agama, kesusialaan, adat istiadat, sopan santun dan norma hukum. Di dalam norma-norma tersebut diatur syarat-syarat apa saja yang berlaku untuk menyalurkan libido yang selalu menuntut untuk dilampiaskan tersebut. Misalnya di dalam norma hukum diatur pada usia berapa orang boleh melakukan hubungan seksual atau dalam norma kesusilaan kesopanan diatur orang tidak boleh menunjukan nafsu birahi melalui bahasa tubuh di depan pihak lain yang bukan istrinya atau dalam norma agama orang boleh melakukan hubungan seksual apabila dia sudah resmi menikah dengan pasanganya yang sudah dewasa.

Libido yang demikian terpenjara di dalam tubuh manusia dan dia selalu meronta-ronta untuk dilampiaskan. Pengalihan libido ke dalam bentuknya yang positif, norma sosial saja tidak cukup harus ada kontrol yang ketat secara kolektif dari masyarakat setempat. Hal ini dibarengi pula dengan kontrol yang tegas dan ketat terhadap pemberlakuan dan penataan norma-norma sosial yang ada. Jika kontrol secara kolektif ini tidak dilakukan maka hal ini tidak menutup kemungkinan akan mendorong munculnya tindakan-tindakan pengalihan libido dalam bentuknya yang negatif. Pengalihan dalam bentuk yang negatif inilah yang dinamakan dengan kekerasan seksual. Jika hal ini terjadi maka anak-anaklah yang paling rentan mengalami serangan seksual dari orang dewasa. ${ }^{33}$

Sedangkan untuk penyebab terjadinya kekerasan seksual terhadap anak-anak sangat luas sekali, tidak ada satupun yang merupakan sebab khusus atau sebab

${ }^{32}$ Ruth Berry. (2001) Seri Siapa Dia? Freud. Jakarta: Erlangga.

33 Ismantoro Dwi Yuwono. (2015). Penerapan Hukum Dalam Kasus kekerasan Seksual Terhadap Anak. Yogyakarta: Pustaka Yustisia. h. 8. 
tunggal terjadinya tindak kekerasan seksual pada anak-anak yang terjadi di Indonesia. Hal tersebut dapat disebabkan oleh keseluruhan hal yang terdiri dari bemacam-macam kondisi serta persoalan yang berbeda-beda. Anak-anak baik laki-laki maupun perempuan merupakan kelompok yang rentan menjadi korban kekekerasan seksual. Mereka yang menjadi korban sebagian besar berasal dari keluarga yang rentan. Dilihat dari sudut pandang pelaku kejahatan seksual, menurut Hari secara umum dapat disebutkan bahwa faktor-faktor penyebab terjadinya kejahatan seksual pada anak dibagi menjadi 2 (dua) bagian yaitu faktor interen dan faktor eksteren. ${ }^{34}$

\subsubsection{Faktor Interen}

Faktor interen adalah faktor-faktor yang terdapat dalam diri individu. Faktor ini khusus dilihat pada diri individu dan hal-hal yang mempunyai hubungan dengan kejahatan seksual. Pertama, Faktor Kejiwaan atau keadaan diri yang tidak normal dari seseorang dapat mendorong seseorang melakukan kejahatan. Misalnya, nafsu seks yang abnormal dapat menyebabkan pelaku melakukan pemerkosaan terhadap korban anak-anak dengan tidak menyadari keadaan diri sendiri. Psikologis (kejiwaan) seseorang yang pernah menjadi korban pemerkosaan sebelumnya seperti kasus Emon yang kejiwaannya telah terganggu sehingga kerap melakukan kejahatan seksual pada anak. Kedua, Faktor Biologis. Pada realitanya kehidupan manusia mempunyai berbagai macam kebutuhan yang harus dipenuhi. Kebutuhan biologis itu terdiri atas tiga jenis, yakni kebutuhan makanan, kebutuhan seksual dan kebutuhan proteksi. Kebutuhan seksual sama dengan kebutuhan-kebutuhan lain yang menuntut pemenuhan.

Ketiga, Faktor Moral. Moral merupakan faktor penting untuk menentukan timbulnya kejahatan. Moral sering disebut sebagai filter terhadap munculnya perilaku menyimpang. Pemerkosaan, disebabkan moral pelakunya yang sangat rendah. Keempat, Balas Dendam Dan Trauma Masa Lalu. Pelaku tindak pidana kekerasan seksual terhadap anak-anak terdorong ingin balas dendam dan dipengaruhi apa yang pernah dialaminya saat menjadi korban, kemudian ada motivasi mau merasakan kembali apa yang pernah dirasakan. Dalam beberapa kasus terutama pelaku kejahatan seksual sejenis, terutama yang dilakukan oleh orang terdekat seperi guru dalam asus kekerasan seksual yang dilakukan oleh AW (23) Guru honorer di SD Negeri 10 Tugu Cimanggis Depok, Jawa Barat. Profil pelaku ternyata dikenal sebagai orang yang berkperribadian baik selama menjadi guru honorer dan aktif dalam kegiatan kesiswaan di sekolah.

\subsubsection{Faktor External}

Faktor eksteren adalah faktor-faktor yang berada di luar diri si pelaku. Pertama, Faktor Budaya. Dalam kehidupan sehari-hari hubungan antara orang dewasa dan anak-anak terbentuk dalam pola hubungan yang menguasai, atau yang disebut relasi kuasa. Hal ini disebabkan pandangan yang melekat bahwa anak menjadi hak kepemilikan bagi orang tua atau orang dewasa lainnya. Tidak dapat dipungkiri bahwa kondisi seperti ini telah menyebabkan tidak sedikit anak yang telah menjadi korban dari kekerasan seksual (sexual abuse) dan penelantaran (neglect). Meskipun anak masih berada satu atap dengan orang tua maupun wali asuhnya, tidak menutup

${ }^{34}$ Wickman, Randel Easton, Janet West. (2002) Therapeutic Work with Sexually Abused Children Abused. London: SAGE Publications. 
kemungkinan anak bersangkutan menjadi korban kekerasan dan penelantaran. Hal ini ditunjukan dengan pemberitaan di media massa yang memaparkan kekerasan terhadap anak yang dilakukan oleh orang yang mempunyai hubungan darah denganya dan bertempat tinggal dalam rumah yang sama. ${ }^{35}$ Kedua, Faktor Ekonomi (Kondisi Anak Terlantar). Faktor ekonomi yang berujung pada masalah kemiskininan merupakan salah satu sebab klasik yang menurut beberapa hasil peneltian. Kemiskinan yang begitu berat dan berdampak pada langkahnya kesempatan kerja mendorong jutaan penduduk Indonesia untuk melakukan migrasi di dalam dan keluar negeri untuk menemukan cara agar dapat menghidupi diri mereka dan keluarga mereka sendiri. Kemiskinan bukan merupakan satu-satunya indikator kerentanan seorang anak mengalami kekerasan seksual. Tapi telaah data menunjukan ada ratusan bakan ribuan anak dari keluarga miskin yang menjadi korban kekerasan seksual. Anak-anak yang yang berasal dari keluarga miskin dan ditelantarkan dan hidup dijalanan cenderung diperlakukan secara salah dan berpotensi menjadi obyek kekerasan seksual.

Menurut Kasi Rehsos Korban Tindak Kekerasan Anak Kementrian Sosial "anak-anak korban kekerasan seksual yang ditangani oleh Direktorat Rehabilitasi Anak teritama yang berasal dari keluarga miskin di mana, pelakunya orang terdekatnya seperti bapak kandung/tiri, ternyata banyak dari para bapak-bapak ini ditinggal pergi oleh istrinya untuk bekerja sebagai TKW di luar negeri. Kondisi ini membuat para bapak ini mengalami kesepian dan sebagai pelampiasanya di lakukan pada anak-anak terutama anak perempuan. Kondisi ini berlangsung berulang-ulang dan para korban tidak berani melapor kepada siapa-siapa karena mereka berada dalam tekanan dan takut akan kehilangan orang tuanya. Ada juga keluarga terdekat yang melihat gelagat adanya kekerasan seksual tersebut tapi tidak berani melapor karena tadi terjadi konflik". ${ }^{36}$

Potensi terjadinya kekerasan seksual terhadap anak-anak rentan tidak hanya pada anak perempuan tapi juga anak lai-laki. Ketua Lembaga Perlindungan Saksi dan Korban (LPSK) Abdul Haris Semendawai mengatakan, di awal tahun 2018, tren kasus kekerasan seksual khususnya terhadap anak menunjukkan peningkatan. Korbannya pun tak cuma perempuan. Malahan, jumlah anak korban berjenis kelamin laki-laki justru makin banyak. Menurut Semendawai, satu orang pelaku bisa memakan lebih dari satu korban. Contoh seperti pada kasus di Tangerang dengan pelaku W alias Babe, yang korbannya mencapai 43 orang.

Ketiga, Minimnya Kesadaran Kolektif Terhadap Perlindungan Anak di Lingkungan Pendidikan. Maraknya tindak pidana kekerasan seksual terhadap anak-anak khususnya di tahun 2018 yang menyita perahatian publik. Kasus kekerasan seperti pemerkosaan yang dilakukan oleh orang-orang terdekat, kasus pedofilia, sodomi, perdagangan anak untuk eksploitasi seksual hingga pembunuhan yang diberitakan di media massa. Kasus kekerasan seksual yang dilakukan oleh oknum guru SDN Tugu Depok terhadap belasan siswa menunjukan bahwa sekolah yang seharusnya menjadi tempat yang aman dan ramah terhadap anak sudah mengalami degradasi fungsi. Undang-Undang Nomor 23 Tahun 2002 tentang Perlindungan Anak (UUPA) menempatkan 5 (lima) pilar penyelenggara perlindungan anak yakni, orang tua,

${ }^{35}$ Melly Setyawati dan Supriyadi Widodo Eddyono. (2007). Perlindungan Anak dalam Rancangan KUHP. Jakarta: ELSAM dan Aliansi Nasional Reformasi KUHP. h. 4.

${ }^{36}$ Wawancara dengan dengan Kasi Rehsos Kemensos Anak Korban Tindak Kekerasan, Jumat 7 Juni 2018 Pukul. 11.00 WIB. 
keluarga, masyarakat, pemerintah dan negara. Pihak-pihak ini bertanggungjawab secara bersama-sama untuk mewujudkan kehidupan sosial yang ramah anak dan menjamin perlindungan maksimal terhadap kepentingan dan kebutuhan anak.

Namun peran kolektif ini belum sepenuhnya disadari oleh semua pihak khususnya di dunia pendidikan, UUPA justru sering kali dianggap menjad "monster" bagi para pendidik untuk melakukan aktivitas pendidikan. Disatu sisi guru ingin menegakan aturan dengan prinsip reward and punishment, di sisi lain guru juga takut jika diangggap melakukan kekerasan yang ancaman hukumnya hukumanya cukup tinggi. UUPA juga disinyalir seringkali menjadi pintu kriminalisasi bagi guru dalam menjalankan tugas dan kewajibanya. Kegamangan seperti ini, mau tidak mau harus dicarikan solusi agar tidak merugikan anak dalam jangka panjang.

Keempat, Paparan Pornografi Anak Dan Pornografi Dewasa yang Mengorbankan Anak. Perkembangan media era global saat ini membawa pengaruh besar terhadap perkembangan anak-anak. Globalisasi saat ini yang ditandai dengan perkembangan media terutama media sosial. Bahaya pornografi pada anak adalah karena konten ini menghancurkan dirinya. Anak-anak yang terpapar pornografi akan mengakibatkan kerusakan otak sehingga anak berpotensi mengalami gangguan secara psikis dan emosional terutama disaat anak beranjak dewasa dan kondisi ini menjadi pemicu munculnya kekerasan seksual akhir-akhir ini. Perilaku anak yang kecanduan pornografi sangat berbeda dengan anak yang seusianya. Berdasarkan hasil penelitian Balai Besar Penelitian dan Pengembangan Pelayanan Kesejahteraan Sosial Yogyakarta (B2P3KS) bekerja sama dengan End Child Prostitution, Child Pornography \& Trafficking Of Children for Sexual Purposes (ECPAT) Indonesia. ${ }^{37}$ Faktor pornografi berada di peringkat pertama dengan $43 \%$, diikuti pengaruh teman $33 \%$, pengaruh narkoba/obat $11 \%$, pengaruh histori pernah menjadi korban atau trauma masa kecil $10 \%$ dan pengaruh luar $10 \%$.

Perkembangn Informasi dan Teknologi (gadget) yang memungkinkan transfer dan transimisi materi bermuatan pornografi secara cepat dan langsung ke telapak tangan. Konsekuensi perkembangan teknologi informasi, menimbulkan beragam kejahatan di dunia cyber (maya). Salah satunya kejahatan (tindak pidana) itu berupa pornografi menggunakan media di internet (cyberporn). Perkembangan teknologi informasi membawa perubahan besar dan mendasar pada tatanan sosial dan budaya dalam skala global. Dengan menggunakan internet, pengguna diberi kemudahan untuk berkelana, menembus batas kedaulatan suatu negara, batas budaya, agama, politik, ras, hierarki birokrasi. Berbagai kemudahan untuk mengakses dan menembus tanpa batas ini, dimanfaatkan untuk menyebar pornografi.

Pornografi menjadi hal yang menakutkan ketika disalahgunakan. Pornografi dapat merangsang timbulnya tindak pidana lain. Penayangan pornografi pada saat yang tepat, dapat membangkitkan gairah seksual yang meningkat dan menuntut penyaluran hasrat dengan segera, tetapi sering sulit dilaksanakan. Hal ini yang menjadi permasalahan ketika pornografi disalahgunakan. Pornografi menjadi perangsang yang kuat bagi penerimanya, yang apabila disalurkan dengan cara yang salah akan mengakibatkan pelecehan seksual ringan hingga berat.

${ }^{37}$ SindoNew.com. diakses Sabtu 8 Juni 2018 pukul 12.00 WIB. 
Pornografi kini tersedia lebih beragam dan dapat dijangkau dengan sangat mudah bahkan murah oleh siapa pun termasuk anak-anak dan remaja. Bicara masalah pornografi, berarti kita harus menyiapkan diri untuk mengetahui mulai dari efek kecanduan sampai efek pelampiasan hasrat seksual yang diakibatkan materi-materi pornografi. Itu berarti, bicara pornografi tidak bisa kita lepaskan dari masalah-masalah perilaku-perilaku seksual sampai kejahatan-kejahatan seksual. Pokok materi yang terdapat di internet yang secara spesifik menjual gambar-gambar erotik dan informasi porno yang isinya tidak senonoh atau cabul dan sengaja dimaksudkan untuk membangkitkan nafsu seksual para pengaksesnya disebut dengan situs porno, dan lagi-lagi yang menjadi korban untuk dijadikan sasaran ialah anak. ${ }^{38}$

Kelima, Lemahnya Penegakan Hukum dan Ancaman Hukuman yang Relatif Ringan. Proses hukum yang harus dilalui oleh seorang korban tindak kekerasan seksual memerlukan pengorbanan mental yang sangat tinggi membuat korban dan keluarga korban menghindari proses tersebut. Proses hukum yang rumit, berbeli-belit dan kerap tidak manuasiawi membuat korban mengalami situasi seperti ibarat pepatah "sudah jatuh tertimpah tangga". Keenam, Disharmoni Antar Produk Perundang-Undangan Terkait Masalah Anak. Sejak era reformasi, pemerintah telah menerbitkan aneka jenis produk hukum dan perundang-undangan yang memuat pasal-pasal yang memiliki keterkaitan dengan masalah anak. Entah karena dalam penyusunanya tidak memiliki sensitivitas terhadap perlindungan kepentingan atau karena tidak mengacu UUPA, produk hukum dan perundang-undangan yang lahir tersebut tidak sinkron satu sama lain dan belum ada harmonisasi dalam pelaksanaanya, di mana masih terjadi paradoksialitas satu sama lain ketika menyangkut masalah-masalah anak. Pada tahap sinkronisasi ini UUPA seharusnya bisa menjadi penjuru atau rujukan setiap regulasi yang disusun dan terkait dengan masalah anak khusnya terkait dengan tindak kekerasan seksual. Akibatnya pemerintah, penegak hukum dan masyarakat sukar menerapkannya terhadap perlindungan anak dan pemenuhan kebutuhan hak-hak anak.

Ketujuh, Anak dalam Siatuasi Bencana dan Gawat Darurat. Salah satu faktor mempengaruhi kemungkinan terjadinya kekerasan seksual dan eksploitasi seksual terhadap anak adalah tahapan-tahapan dalam siatuasi gawat darurat. Setelah terjadinya bencana anak-anak dihadapkan pada resiko-resiko, khususnya seperti terpisah dari orang tua yang dapat membuat mereka rentan terhadap perdagangan dan penculikan atau kekerasan seksual. Selama tahap pemberian bantuan dan pemulihan anak-anak semakin rentan untuk mengalami perlakuan salah melalui pelacuran sebagai cara untuk bertahan hidup.

Selama terjadinya bencana, struktur kehidupan anak-anak menjadi terbalik, diantara berbagai resiko yang harus dihadapi oleh anak-anak dan remaja adalah kekerasan seksual dan eksploitasi seksual. Sudah dimaklumi bahwa semua jenis kekerasan akan meningkat selama dan pasca terjadinya sebuah bencana dan selalu diingat orang dewasa akan mengalami berbagai tekanan atau masalah ekonomi sebagai akibat dari situasi gawat darurat. ${ }^{39}$ Kekerasan seksual dapat dapat terjadi selama terjadinya bencana dan pasca terjadinya bencana dan menjadi potret kehidupan anak-anak dalam jangka panjang. Diketahui bahwa kekerasan seksual

${ }^{38}$ Beniharmoni Harefa. (2016). Kapita Selekta Perlindungan Hukum bagi Anak. Yogyakarta: Deepublish.

39 World Health Organisation. "Violence and Disaaters". Diakses dari http://www.who.int/violence_injury_prevention/publication/violence_disaster.pdf 
tersebut akan meningkat pasca terjadinya bencana karena disintegrasi masyarakat dan sosial yang lebih luas dan dalam masyarakat yang menjadi korban bencana. Normanorma dan larangan-larangan sosial yang biasanya menjadi faktor penghambat dan melemah karena konflik kemiskinan dan pemindahan.

Dalam kondisi gawat darurat akibat peperangan kekerasan seksual dan eksploitasi seksual tentu sangat erat kaitan dengan tentara anak karena kekerasan seksual tersebut sering terjadi dalam konteks anak-anak, yang di rekrut secara paksa kedalam angkatan bersenjata. Anak-anak perempuan secara khusus sering direkrut secara paksa dan dimanfaatkan sebagai "budak seks". Walaupun hal ini sering dianggap sebagai sebuah cara untuk melindungi diri mereka sedndiri dan keluarga dari kekerasan fisik dan seksual dalam siatuasi konflik. Dalam situasi seperti ini anakanak dan remaja dapat mengalami pelecehan seksual secara berulang-ulang yang dilakukan oleh seseorang yang sangat berpengaruh maupun teman-temanya. ${ }^{40}$

Kedelapan, Dampak Pengembangan Indistri Pariwisata. Dibalik dampak postif dari pengembangan kawasaan pariwisata di sejumlah daerah, juga dampak negative terhadap perkembangan perlindungan anak. Sejumlah destinasi wisata diduga menjadi tempat eksploitasi seksual terhadap anak. Data ECPAT perwakilan Indonesia sepanjang tahun 2005-2017 pada beberapa tempat kunjungan wisata di Tanah Air seperti Batam, Jakarta, Bali , Bandung, Bogor, Surabaya dan Medan, merupakan daerah yang rentan terhadap eksploitasi seksual anak dan menjadi pintu gerbang masuknya turis-turis asing terjadi praktik eksploitasi seksual dan "prostitusi terselubung" terhadap anak perempuan dan laki-laki. Fenomena anak-anak di daerah wisata yang menjadi korban eksploitasi dijumpai dalam berbagai macam modus. Fenomena eksploitasi seksual terhadap anak-anak berlangsung bertahun-tahun, tapi tidak banyak mencuat ke publik. Masyarakat dan pemerintah cenderung permisif karena merasa pariwisata menguntungkan daerahnya. Ditemukan beberapa fenomena eksploitasi seksual terhadap anak di sektor travel dan pariwisata yaitu, prostitusi anak, prostitusi dalam jaringan (daring), pedofilia, wisata seks dan "kopi pangku". ${ }^{41}$

Pariwisata Seks Anak (PSA) merupakan bentuk eksploitasi terhadap anak di daerah pariwisata yang melibatkan pemberian uang, pakian, makanan atau dalam bentuk kebaikan lainnya terhadap anak langsung atau melalui perantara yang dilakukan oleh orang-orang dalam perjalanan atau wisatawan untuk melakukan hubungan seksual dengan anak. PSA dapat terjadi dalam kurun waktu yang lama khususnya jika dalam proses "grooming" di mana sang pelaku berteman dengan anak yang rentang dan berusaha mendapatkan kepercayaan sebelum dieksploitasi. Pelaku PSA bisa siapa saja baik laki-laki maupun perempuan, dan bisa terjadi di mana saja di

40 Stephanie Delanie, ECPAT International, Penelitian Asli Amita Naik, Melindungi Anak-Anak dari Eksploitasi Seksual \& Kekerasan Seksual Situasi Bencana \& Gawat Darurat. Terjemahan Ramlan (PKPA) Publikasi ECPAT Indonesia.

${ }^{41}$ ECPAT (End Child Prostitution, Child Pornografy and Trafficking os Children for Sexual Purpose) Indonesia adalah organisasi jaringan Internasional yang bekerja bersama sejumlah organisasi di Indonesia yang aktif menentang praktik eksploitasi seksual komersil anak. ECPAT Internasional adalahsebuah jaringan organisasi yang berada di lebih dari 75 negara yang bekerja untuk menghapus semua bentuk eksploitasi seksual anak. 
seluruh penjuru dunia, karena tidak ada satu negarapun yang kebal terhadap pariwisata seks anak. Pelaku PSA dapat dikelompokan dalam menjadi 3 kategori.

Pertama, Wisatawan Seks Anak Situasional. Pelaku ini melakukan kekerasan terhadap anak dengan cara coba-coba karena ada kesempatan. Pelaku ini tidak memiliki kecendrungan seksual khusus terhadap anak-anak dan kebanyakan wisatawan seks anak adalah pelaku situasional. Kedua, Wisatawan Seks Anak Preferensial. Pelaku ini menunjukan sebuah pilihan seks aktif terhadap anak. Walaupun pelaku masih memiliki kemampuan untuk tertarik terhadap orang dewasa, tetapi mereka akan mencari anak-anak yang umumnya masih masa puber atau remaja untuk berhubungan seksual. Ketiga, Pedofil. Pedofil menunjukan sebuah kecendrungan seksual khusus terhadap anak-anak yang belum puber.

Para korban PSA adalah anak-anak, baik anak laki-laki maupun perempuan dan sering kali terjerat dalam kemiskinan, berasal dari kelompok minoritas, anak-anak yang bekerja, anak-anak yang hidup di jalanan, anak-anak yang menjadi korban kekerasan dan penelantaran di rumah. Para korban mengalami dampak emosional, psikologis, dan fisik yang berat. Kekerasan fisik yang dialami dapat mengakibatkan luka, rasa sakit dan takut, sedangkan masalah psikologis yang ditimbulkan adalah rasa bersalah, rendah diri, depresi, dan dalam beberapa kasus dapat menyebabkan bunuh diri mereka juga rentan terhadap HIV/AIDS. Mereka mengalami stigmatisasi dari masyarakat selain itu berdampak juga terhadap kesehatan, kesejahteraan dan berbagai kesempatan di masa depan terancam oleh eksploitasi yang mereka alami. ${ }^{42}$

Prostitusi komersil anak dapat dijumpai di dalam pusat-pusat hiburan, seperti bar, kafe, kelab, spa, hotel dan fasilitas karaoke. Selain tempat karaoeke, layanan seksual di apartemen belakangan menjadi trend di Indonesia. Sejumlah apartemen yang terinegrasi dengan pusat perbelanjaan diduga menjadi tempat praktik prostitusi tersebut. Begitu juga dengan praktik wisata seks yang jamak dijumpai di wilayah Puncak Bogor, Jawa Barat. Modus dilakukan sejumlah wisatawan dengan praktik kawin kontrak dengan perempuan setempat, termasuk anak-anak. Demikian juga dengan fenomena "kopi pangku" di Kalimantan Barat yaaitu mengeksploitasi anak usia 12-15 tahun. Modusnya anak duduk dipangkuan laki-laki dewasa yang mampir di warung kopi.

Pedofila juga menjadi trend eksploitasi seksual, terutama di daerah wisata seperti Bali. masyarakat tidak menyadari bahwa tidak semua turis datang ke daerah untuk melihat keindahan alam saja, tapi untuk kepentingan seksual. Umumnya para turis menyasar anak-anak dari keluarga miskin yang dekat dengan lokasi wisata, seperti anak-anak pedagang asongan dan buruh. di daerah wisata tertentu ada ada trend predoator seksual menyasar anak laki-laki yang menjadi pemuas seksnya. Dampaknya dalah adanya fenomena para korban kemudian terjerumus dalam bisnis prostitusi karena terpapar budaya konsumerisme. Mereka kemudian membawa temanya kepada laki-laki dewasa. Artinya ada fenomen baru di mana dalam beberapa kasus justru mereka menawarkan diri. Modus lain yang dilakukan sejumlah predator seksual anak-anak adalah menyasar anak-anak di daerah pedesaan dengan modus lain, misalnya menjadi orang tua asuh, dan melakukan bantuan ke sejumlah pendidikan anak usia dini (PAUD) dan taman kanak-kanak (TK), dengan demikian mereka dapat berakitifitas secara bebas dengan anak, kemudian mereka melakukan pelecehan seksual. Donasi atau menjadi penderma adalah cara pelaku kekerasan

$\begin{array}{ccccc}{ }_{2}^{42} & \text { "Pariwisata Seks } & \text { Anak } & \text { Mengancam } & \text { Kita!" Diakses } \\ \text { http://wwww.unwto.org/protect_children. }\end{array}$


seksual untuk memanipulasi aktifitasnya dan menipu masyarakat agar dapat leluasa melakukan aksinya.

Dampak lain dari praktik eksploitasi di daerah wisata adalah sejumlah anakanak korban kekerasan seksual baik laik-laki maupun perempuan dimanfaatkan pelaku prostitusi anak sebagai perantara untuk memudahkan pencarian korban lain. Modusnya dengan berbagai cara, salah satunya adalah korban diiming-imingi bayaran jika bisa mengajak temanya, masuk dalam kegiatan mereka. Anak-anak tidak hanya menjadi korban tapi didoktrin oleh pelaku untuk menjadi pelaku kekerasan seksual dikemudian hari. Doktrin ini membuat anak menjadi kekerasan seksual dikemudian hari. Data dari ECPAT Indonesia tahun 2015 menunjukan tiga model pelaku kekerasn seksual anak, yaitu pertama, menjadikan anak sebagai target pemuas seks. Kedua, menjadikan anak sebagai kader yang akan melakukan kekerasan seksual dikemudian hari dan ketiga, menjadikan anak sebagai perantara.

\section{Kesimpulan}

Kekerasan seksual terhadap anak adalah hubungan atau interaksi antara seorang anak dan seorang yang lebih tua atau orang dewasa seperti orang asing, saudara kandung atau orang tua di mana anak dipergunakan sebagai obyek pemuas kebutuhan seksual pelaku. Perbuatan ini dilakukan dengan menggunakan paksaan ancaman, suap, tipuan bahakan tekanan. Bentuk-bentuk kekerasan seksual itu sendiri ada 2 (dua) bentuk yakni segala bentuk eksploitasi dan kekerasan seksual terhadap anak yang dilakukan oleh orang dewasa.

Maraknya kasus kekerasan seksual yang terjadi pada anak akhir-akhir ini dapat dikatakan sebagai multi faktor. Adapun faktor-faktor tersebut dapat teridentifikasi sebanyak dua yakni faktor internal dan eksternal. Adapun faktor internal yaitu sebab yang berasal dari dalam diri pelaku kekerasan seksual seperti faktor kejiwaan, faktor biologis, faktor moral, faktor balas dendam dan trauma masa lalu. Sedangkan faktor eksternal dapat teridentifikasi beberapa faktor sebagai berikut faktor budaya, faktor ekonomi, faktor minimnya kesadaran kolektif terhadap perlindungan anak di lingkungan pendidikan, faktor paparan pornografi anak dan pornografi dewasa yang mengorbankan anak, faktor lemahnya penegakan hukum dan ancaman hukuman yang relatif ringan, faktor disharmoni antar produk perundang-undangan terkait masalah anak, faktor anak dalam situasi bencana dan gawat darurat.

\section{Daftar Pustaka/Daftar Referensi}

\section{$\underline{\text { Buku }}$}

Asmita, A. (2014) Melindungi Anak-Anak dari Eksploitasi Seksual dan Kekerasan Seksual Situasi Bencana dan Gawat Darurat. ECPAT Indonesia.

Atmasasmita, R. (1995). Kapita Selekata Hukum Pidana dan Kriminologi. Bandung: Mandar Maju.

Atmasasmita, R. (2005). Teori dan Kapita Selekta Kriminologi. Bandung: Refika Aditama. 
Aziz, A. (1998) Aspek Hukum Perlindungan Anak. Medan: USU Press.

Berry R. (2001). Seri Siapa Dia? Freud. Jakarta: Erlangga.

Brasil, D. (2005). Bisnis Seks di Singapura. Jakarta: Pustaka Primatama.

Clinard, M. B. \& Quiney, R. (1973). Criminal Behavior Syatem A Typologi. Holt Renehart and Winscton Inc.

Douglas, J. D. dan Waksler, F. C. (2002). Teori-Teori Kekerasan. Jakarta: Ghalia Indonesia dan Universitas Kristen Petra.

ECPAT International. (2012). Global Report on Situation of Comercial Sexual Exploitation of Children in Indonesia. Bangkok: ECPAT International.

Eddyono, S. W., Sofian, A., Akbari, A. R. (2016). Menguji Efuria Kebiri; Catatan Kritis atas Rencana Kebijakan Kebiri (Chemical Castration) Pelaku Kejahatan Seksual Anak di Indonesia. Jakarta: Institit for Criminal Justice Reform, ECPAT Indonesia, MAPPI FH UI, Koalisi Perempuan Indonesia, Aliansi 99 Tolak Perppu Kebiri.

Farid, M. (1997). Kejahatan Seksual Terhadap Anak: Implementasi Konvensi Hak Anak (di Indonesia) dan Agenda Aksi dari Stockholm. Jakarta.

Fromm, E. (2000). The Anatomi of Human Destructivenes, diterjemahan oleh Imam Mutaqqin. Judul Akar Kekerasan Analisis Sosio-Psikologis atas Watak Manusia. Yogyakarta: Pustaka Pustaka Pelajar.

Garner, B. A. (2014). Black's Law Dictionary Tenth Edition. Eagen US: Publisher Thomson West Aspostone Books.

Gosita, A. (2004). Masalah Korban Kejahatan, Jakarta: Bhuana Ilmu Populer.

Harefa, B. (2016). Kapita Selekta Perlindungan Hukum bagi Anak. Yogyakarta: Deepublish.

Hawari, D. (2013). Kekerasan Seksual pada Anak. Jakarta: UI Press.

Hertinjung, W. S. The Dinamyc of Causes of Child Sexual Abuse Based on Availability of Personal Space and Privaci. Surakarta: Fakultas Psikologi Universitas Muhamadiyah Surakarta.

Hurairah, A. (2012). Kekerasan Seksual Terhadap Anak. Bandung: Nuasa Press.

Irsan, K. (2007). Hukum Perlindungan Anak. Jakarta: Fakutas Hukum Universitas Pembangunan Nasional Veteran Jakarta.

Lexy, M. (2014). Metodologi Penelitian Kualitatif. Bandung: Remaja Rosdakarya.

Mansur, R. (2010). Mediasi Penal Terhadap Perkara Kekerasan Dalam Rumah Tangga. Yayasan Gema Yustisia Indonsia. 
Munti, R. B. (2000). Kejahatan Seksual. Jakarta: Pusat Kajian Wanita Universitas Indonesia.

Noviana, I. Kekerasan terhadap Anak; Dampak dan Penagananya (Child Sexual Abuse: Ipact and Hendling) Jakarta: Pusat Penelitian dan Pengembangan Kesejahteraan Kemensos Republik Indonesia.

Purwandari, K. (2006). Penguatan Psikologis untuk Menganggulangi Kekerasan Dalam Rumah Tangga dan Kekerasan Seksual. Jakarta: Program Kajian Wanita Pascasarjana Universitas Indonesia.

QC, G. R. (2000). Kejahatan Terhadap Kemanusiaan (Perjuangan Untuk Mewijudkan Keadilan Global). Jakarta: Komnas HAM RI.

Setyawati, M., Eddyono, S. W. (2007). Perlindungan Anak dalam Rancangan KUHP. Jakarta: ELSAM dan Aliansi Nasional Reformasi KUHP.

Soesilo, R. (1996). Kitab Undang-Undang Hukum Pidana (KUHP) Serta KomentarKomentarnya Lengkap Pasal Demi Pasal. Bogor: Pelita.

Sumiarni, E. (2003). Perlindungan Hukum Terhadap Anak Dalam Hukum Pidana. Yogyakarta: Unika Atmajaya.

Suyanto, B., Hariadi, S. S., Nugroho, P. A. Tindak Kekerasan Terhadap Anak, Masalah dan Upaya Pemantauan, Kerja Sama Lembaga Perlindungan Anak (LPA) Jawa Timur dan UNICEF, Surabaya: Lutfansa Mediatama.

Thamrin, M. I. dan Farid, M. (2010). Panduan Bantuan Hukum Bagi Paralegal. Yogyakarta: LBH Yogyakarta bekerja dengan TIFA Foundation.

UNICEF, Efectife Strategies to Combat Sexual Violence Against Women and Children: A Background Analysis.

Wickman, R. E., West, J. (2002). Therapeutic Work with Sexually Abused Children Abused. London: SAGE Publications.

Yayasan Lembaga Bantuan Hukum Indonesia. (1997). 1996: Tahun Kekerasan, Potret Pelanggaran HAM. Jakarta: YLBHI.

Yuwono, I. D. (2015). Penerapan Hukum Dalam Kasus Kekerasan Seksual terhadap Anak. Yogyakarta: Putaka Yustisia.

\section{$\underline{\text { Website Resmi }}$}

A27,

"Pedofilia dalam Dunia

Maya", https://pinterpolitik.com/pedofilia_dalam_dunia_maya1/ 
Pariwisata Seks Anak Mengancam Kita! ECPAT International Protect@ecpat. Net http://www.unwto.org/protect_children

Sari, A P. "Penyebab Kekerasan Seksual terhadap Anak dan Hubungan dengan Pelaku" diakses dari http://kompas .com/indeks.php/red.

World Health Organisation" Violence and Disaaters htt://www.who.int/violence_injury_prevention/publication/violence_disaster.pdf

\section{Jurnal}

Anwar, M. J. (2002). “Kekerasan dan Anti Kekekrasan”. Majalah Amanah. 31(16).

Mukodin., Sri F. H. (2015). Dampak Psikologis Pada Kehamilan Remaja, Midwiferia. 1(2)

Syarifudin, M. H. (2005). Perlindungan Anak. Forum Keadilan. (2)1.

\section{Peraturan Perundang-Undangan}

Undang-Undang Nomor 1 Tahun 1946 tentang Peraturan Hukum Pidana.

Republik Indonesia, Undang-undang Nomor 23 Tahun 2002 tentang Perlindungan Anak. Lembaran Negara Republik Indonesia Tahun 2002 Nomor 109, Tambahan Lembaran Negara Republik Indonesia Nomor 4235.

Republik Indonesia, Undang-undang Nomor 23 tahun 2004 tentang Penghapusan Kekerasan Dalam Rumah Tanggga. Lembaran Negara Republik Indonesia Tahun 2004 Nomor 95, Tambahan Lembaran Negara Republik Indonesia Nomor 4419.

Rancangan KUHP, 2007. Penerbit ELSAM.

Undang-Undang Republik Indonesia Nomor 11 Tahun 2012 tentang Sistem Peradilan Pidana Anak. Lembaran Negara Republik Indonesia Tahun 2012 Nomor 153, Tambahan Lembaran Negara Republik Indonesia Nomor 5332.

Undang-Undang Republik Indonesia Nomor 1 tahun 2016 Tentang Perubahan Kedua Atas Undang-Undang Nomor 23 Tahun 2002 Tentang Perlindungan Anak. Lembaran Negara Republik Indonesia Tahun 2016 Nomor 99, Tambahan Lembaran Negara Republik Indonesia Nomor 5882.

Keputusan Presiden Republik Indonesia Nomor 38 Tahun 1990 tentang Pengesahan Konvensi Tentang Hak-Hak Anak (Convention on the right of the child). Lembaran Negara Republik Indonesia Tahun 1990 Nomor 57.

\section{Lainnya}

“Anak Kehidupan”, Harian Kompas, 26 Januari 2006. 
Catatan Akhir Tahun Komsi Nasional Perlindungan Anak Indonesia. (2014). “Menggugat Peran Serta Keluarga, Masyarakat dan Negara; Memutus Mata Rantai Darurat Kekerasan Terhadap Anak".

Catatan Akhir tahun Komisi Nasional Perlindungan Anak Indonesia. (2015). "Kejahatan Luar Biasa terhadap Anak Makin memperhatinkan, Indonesia Sudah Buat Apa?".

Catatan Akhir Tahun Komisi Nasional Perlindungan Anak Indonesia. (2017). "Peningkatan Efektifitas Kinerja Pengawasan Penyelenggraan Perlindungan Anak".

"Kekerasan Pada Anak Masih Saja Terjadi Hingga Hari Ini". Harian Kompas, 24 Januari 2006.

"Seksualitas, Birahi Manusia, Antara Permainan dan Kesucian". Harian Kompas, 12 Juni 2018.

Wawancara dengan dengan Kasi Rehsos Kemensos Anak Korban Tindak Kekerasan, Jumat 7 Juni 2018 Pukul. 11.00 WIB. 